\title{
Quality of Service in the Banking Sector
}

\author{
Jasmina Lumanaj \\ $P h D$ in progress in Management, \\ Lecturer at Luigj Gurakuqi University, Faculty of Economy. \\ j_lumani@yahoo.com
}

\begin{abstract}
Aulent Guri
$P h D$ in progress in Economy and Sustainable Development at, Environmental Expert at G\&G Group Consults and Projects on Environment and Geoscience, Tirana Albania. aulentguri@gmail.com
\end{abstract}

Armend Aliu

PhD in progress in Finance, Lecturer at University of Prishtina, Faculty of Economy, Kosovo armend_aliu@hotmail.com

\section{Otjela Lubonja}

PhD in progress in Economy and Sustainable Development, Lecturer at Vitrina University, Faculty of Architecture, Tirana Albania otjela@yahoo.com

\section{Doi:10.5901/mjss.2013.v4n9p418}

\begin{abstract}
While observing the various financial institutions in our country we notice the existence of multiple varieties such as: insurance institutions, banks, institutions of social services etc. Among the financial institutions mostly used by businesses and people in general we distinguish the banks. In addition, today's market tendencies have increased the request for financial bank services. As a result, lately the number of banks in our country has increased. This phenomenon has increased customer service, the quality of service and higher competition among banks. Under these conditions it is necessary that banks use aggressive marketing strategies in order to be successful and competitive among their own kind. Due to the increase in market competition, identifying consumer's needs and increasing the quality of service has become a very important trend in today's marketing world. Research has shown that good quality customer service generates better income. While trying to determine what marketing strategies give the edge, academic researchers are trying to figure out what kind of customer service works best in today's environment so that they can improve it. Based on various studies the quality of service has a huge impact on consumer's satisfaction and their loyalty, at the same time it is established as a result of comparison that clients do between the expectations they have for service and their perception of the quality of service rendered. (Parasuraman et al., mentioned in Caruana, 2002). The quality of service has a positive effect in the performance of a bank; as a result it gains competitive advantages due to the improvement of quality of service. As such, what clients think of a service overpasses their expectations for the same service. Caruana, 2002; Chumpitaz, 2004). Due to higher internet access in today's world, the way businesses are managed including the banking business has changed. Consumers are expecting better quality of service, shorter transaction times and better service conditions. However, because the nature of the services, susceptibility, indivisibility, heterogeneity and the quality of services become difficult to be appreciated.
\end{abstract}

\section{Definitions of quality of service}

The quality of service has become an important topic of research among academics especially with the increase of competition. It is now recognized as a key factor in keeping the competitive edge and good quality relations with the clients. (Zeithmal et al., 2000). Gronros (1982) describes the general quality of service as the consumer's perception to distinguish between a rendered service and an expected one. 
The consumer later defines the concept of the expected service as a result of an evaluation process, where he compares his expectations with the service he considers optimal or with the service he has accepted. Similarly, Parasuraman et al., (1985) define the quality of service as a comparison between the consumer's expectations and his view of the service rendered.

After reviewing the literature regarding the services, three main points were suggested:

1. The quality of services is more difficult to be appreciated by the consumers than the quality of products;

2. What consumers think of the quality of the services rendered result from a comparison between consumers' expectations and the actual rendition the services.

3. Quality evaluations are not only based on the results of the service but also they include the evaluations of the process while the service is being rendered.

In addition, Parasuraman et al., (1985) suggested "The Quality of Service Model" which served as the framework for further scientific research in this field. The first picture gives a clearer description of this model. As you can see there are 5 branches:

Figure 1. The Quality of Service Model.

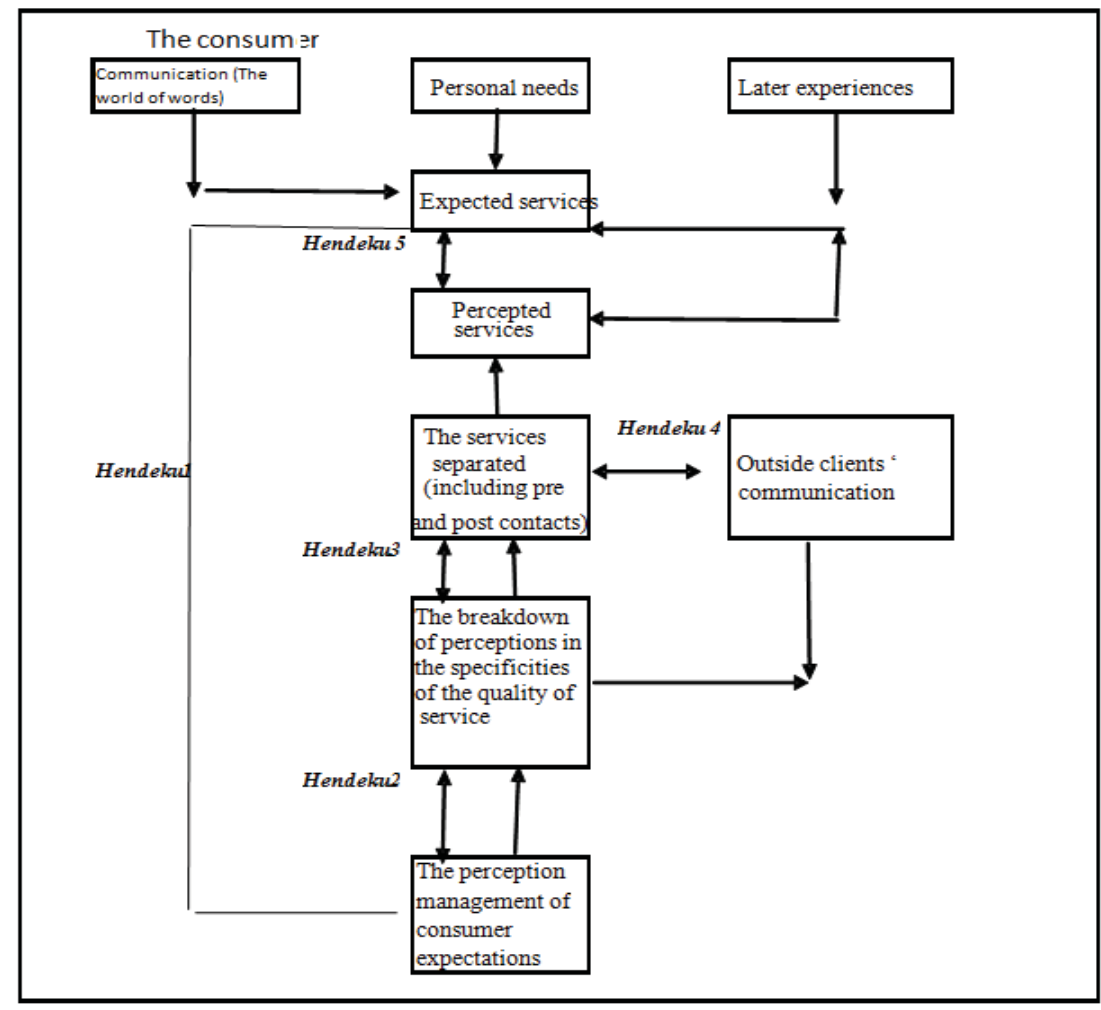

Source: Parasuraman et al., 1985.

This model is specific and a good diagnostic tool. If this model is used in the correct form, it has the potential to help identify the factors that make up good quality of service from the consumer's point of view (Yang et al., 2004). In 1988 Parasuraman et al., explained that the quality of service is the basis of rating the overall services in a company, comparing the companies work with the client's expectations and the way a company should operate. To them the client's impression of service is their general impression, or the way they feel about the superiority of services.

Lately, Page and Spreng (2002) argued that measurement of performance is superior since that is more credible and protected. In addition, they said performance is a stronger indicator of the quality of service than what we expect. The 
conceptual discussion related to the quality of service continues, but this is an indicator that it's a multilevel, multidimensional concept which can mean different things for different researchers in literature (Cronin et al., 2000).

\section{The efficacy of quality of service in banks}

The importance of reaching high levels of quality has been discussed widely in literature, especially when it comes to service, for example Zeithamel, Parasuraman and Berry (1990). The quality of service has been discussed by many authors as a key element to gain competitive advantages. Its importance per the bank industry has been documented in Roth and van der Velde $(1991,1992)$. Today, it's hard to find a bank which hasn't improved the quality of service program.

Fig. 2: The results of a standard model for the operational efficacy of a branch.

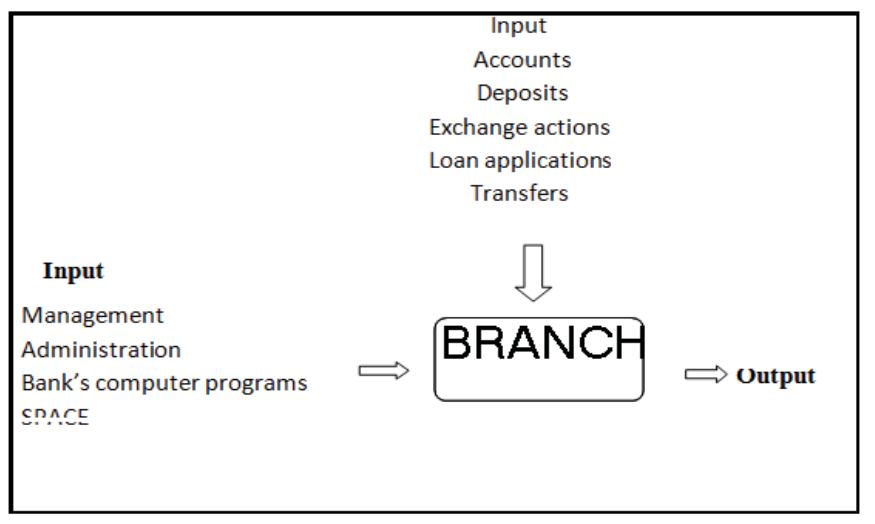

\section{The quality of service in banks, getting consumers' trust and satisfying them.}

The quality of service in banks has a deep impact in consumers' loyalty. This quality is determined based on the comparison between their expectations on the service rendered and what they actually thought of that service.

According to Caruna (2002), the quality of service is divided in two terms, first one being the technical quality, referring to the one transmitted to the consumer and the functional quality which has to do with the final results of the process done for the consumer. At the same time the quality of service has to do with two aspects, the psychological and the behavioral one. They include the access for the one offering the services and the way the service is offered. What the consumer thinks of the service rendered is based on three things: the employees collaborating with consumers, the environment the service is rendered and the results of the service.

The happier the consumers the more loyal they are. In today's bank environments the happiness of the clients could be seen as a considerable success measure, where pleasing the clients could lead to their retention and as a result increased incomes for the bank. (Jamal, Kamal, 2002, Egan, 2004). They describe the consumers' satisfaction as the way the consumer feels about a product or service, because that was used. Egan (2004), based on the definition of a few authors describes the consumer's satisfaction as a psychological process to evaluate the performance results achieved based on certain expectations.

The banks' purpose to increase clientele loyalty is mainly to increase their own incomes. Additional profits could result from clients' loyalty. From organizations prospective loyal consumers lead to increased revenues for the banks, this will result in the sale of predictable services and high revenues.

Most likely the consumers' will need additional services (Gremler and Broen, 1999). To appreciate the importance of the consumer we must look beyond the direct value they have. This means that in addition to the direct revenues one must look at additional revenues. For example, loyal consumers will spread the word around and recommend family and friends to the bank, ths will result in even more revenues for the bank.

Grummerus et al., (2004) has developed four important dimensions for all online services offered by banks:

1. The quality of users services 
2. Reaction

3. The need to refill

4. Security

Fig 3. Four dimensions of online service

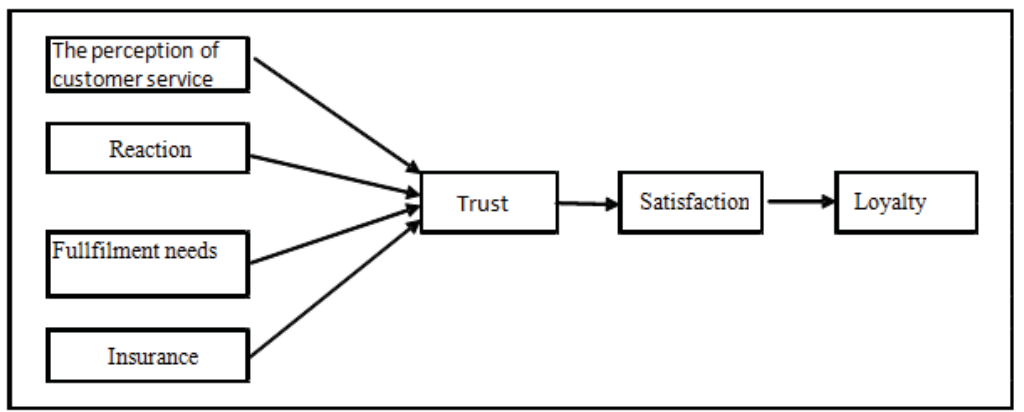

Source: Gummerus et al. (2004)

If these four dimensions are completed, then the client believes in the online service which could lead to the satisfaction and the loyalty of the consumer.

\section{The Quality of Service in Banks}

In this chapter we will talk about the factors influencing the quality of service in Albanian banks and we will describe the survey on the quality of service in our banks.

\subsection{The Factors that influence the quality of service}

\subsubsection{The new computerized systems}

The investments in the new modern technology are done mainly to improve the quality of service which serves mainly to make many processes easier. It also serves to collect, control and develop the information.

\subsubsection{Investment in human resources}

The programs directed towards human resources should aim better classification between the administrative staff and the employees. Continuous education and training at work or through special programs helps in improvement of skills in the bank's staff. Specifically aiming:

1. Qualified staff

2. Improvement of management's skills

3. The skill to select and properly prioritize tasks

To achieve these objectives is important to invest in developing leadership skills, better separation of knowledge, appreciation of initiatives and accomplishments. These are main points to be achieved in order to constantly recruit qualified, devoted employees. The above objective would be reached through:

- It is important to organize trainings in banks by collaborating with domestic and foreign institutions. It would be based on the previously identified needs through an objective way to evaluate performances. Also it's important to adapt to the new growing requests of the institution.

- Identification of potential employees in the management section as well as giving them the opportunity of continuing training.

- Motivate the employees to do more research work in banks.

In order to strengthen the human resources we need to review the proper means. For this reason there should be 
many initiatives that involve various methods. Box 2 gives more information on these initiatives and the methods used.

Box 1. The initiatives used to reach the objectives and the methods used

\begin{tabular}{|c|c|}
\hline $\begin{array}{l}\text { The initiatives used to reach the objectives } \\
\text { On strengthening the human resources: } \\
\text { employee's performance is evaluated } \\
\text { emphasizing individual responsibilities } \\
\text { in fulfilling the objectives of The Albanian } \\
\text { me } \\
\text { Bank. } \\
\text { Development of the methods and } \\
\text { Indicators to monitor these performances, } \\
\text { In order to achieve the objectives previously } \\
\text { determined. }\end{array}$ & $\begin{array}{l}\text { Strengthening of regulations at the base } \\
\text { Continuous testing and reevaluation of the } \\
\text { methods and means used. }\end{array}$ \\
\hline
\end{tabular}

At the same time banks in Albania should keep in mind than an important project is the creation of a separate department in the research field. The purpose would be to conduct research and studies observing the fluctuations in the market including here the new tendencies and consumers' preferences, so that they can respond better to the consumers' needs and preferences.

What this department would do is analyze and expand the information available at the same time create an online report. This online report would improve the quantity, quality and time of the information available. This way the bank is well informed on the changes in the market and can easily adapt to offer better products that the market requests.

Some of the objectives that banks should keep in mind in relation with the clients are:

- Improvement of the public's trust in privately owned institutions

- Improvement of the transparency towards the public (i.e. tell the client how the interest of the deposit is calculated, if he/she is interested; also explain all the terms of the contract before the client signs.

- Increase the level of knowledge the clients' have towards the bank they are operating.

- Communication

\subsection{Study on the consumers' behavior in our country}

In order to observe the important role the consumer has in the services banks offer we have developed a survey. The study focuses on the financial services, the expectations and the consumer's view towards these financial services. In this study we have use traditional variables such as the age, education etc. Also, we have used additional variables in order to better understand the consumer and his behavior. The purpose of this questionnaire is to see what people think using these institutions. To also see if they are happy with the service they receive from banks and the employees' professionalism.

\subsubsection{The procedure as follows:}

The individuals were selected among a heterogeneous population; individuals among different income status and age. These questionnaires were handed inside the banks. In order to see how many times does a consumer go to the bank we asked the question: How many time do you go to the bank? Based on their answers it appears that the majority of people go to the bank a few times a month. The question was directed to those inside the bank and it turns out that they have privately owned businesses so they use the bank for different transactions quite often. But we also have to consider those visiting the bank once every three months; they too have deposits in the bank. An important point of this study is to discover what are some the factors that establish the bank's image in the eyes of the consumer. From the collected answers listed below based on their relevance, the main factors that determine the image of a bank are:

- $\quad$ First contact with the employees 
- The quality of service

- The interests rates and the prices for the services

- Publicity

- Other factors such as hour of operation, parking etc

- The interior design and atmosphere

- Convenient location

Among the criteria on why they should select a certain bank, the consumers listed these elements based on their relevance:

- Interest rates and the services' prices

- Polite behavior

- Reputation

- Friend referral

- The offer of " full service"

- The hours of operation

- Parking

- $\quad$ Special offers for the youth

- Location

When asked "What do you value in a bank employee", consumers listed these factors based on their relevance:

- Communication

- How well do they understand the clients' needs

- Being well-informed

- The speed of service

- The efficiency

\section{Conclusions}

This topic analyzes how important is the quality of services in banks due to the growing competition. The quality of service has turned in an important study and research topic, being now recognized as a key factor in keeping the competitive edge and maintaining good relations with the clients.

The quality of service has a unique contribute to not only the satisfaction of the consumer but his loyalty too. The quality of service has a positive impact especially when considering the competitive advantages that could have been gained from improvement of the quality of service. This way, what consumers think of the service offered is better than what they expected in the first place.

Competition has positively influenced the banks in Albania, and has impacted the need to offer better services for their clients. They can use the new advanced technology, the products, new services and better prices on bank's services.

The survey was created with the purpose to see the important role the consumer has in the banks' service in our country. The age, education and incomes, all influence the banks' services in our country. From this survey it was determined that the main factor determining the image of a bank is the first contact with the staff and their customer service skills. At the same time consumers value communication and the staff's skills.

Even though consumers value the services, is still hard to evaluate the quality of service in banks. Consumers are more interested in the functional quality of services (how is the service rendered) than the dimensions of the technical quality. This is due to the difficulties in distinguishing various qualities of service. This is the reason why managers at every level should keep their focus on the quality of service and measure the consumers' satisfaction related to the quality.

Even though the quality of service has improved, considering this is a new market for our country there's still a lot more to do. Between what consumers expect and the service they actually get there's still a huge difference. The speed of service rendered, the skills, politeness of the staff and the bank's convenient locations are a must for a successful bank.

\section{References}

Banka e Shqiperise. Strategjia e zhvillimit te Bankes se Shqiperise per periudhen 2009 - 2011. 
Cani Sh, Muço M, Baleta T. Sistemi bankar Shqiptar probleme të zhvillimit të tij. Përmbledhje e analizës së vrojtimit. Banka e Shqiperise, Gusht 2000.

Caruana, Albert (2002), "Service Loyalty, The effects of Service quality and the mediating role of customer satisfaction", European Journal of Marketing, Vol. 36 No.7/8, pp. 811-828.

Chumpitaz, Ruben and Paparoidamis, Nicholas G. (2004), Service quality and marketing performance in business-to-business markets: exploring the mediating role of client satisfaction, Managing Service Quality, Vol.14 No. 2/3, pp. 235-248.

Cronin, J., and Taylor, s. (2000), Measuring service quality: a re-examination of extension, Journal of Marketing, Vol. 56 No.3, pp. 55-68.

Davis, F.D. (1989), "Perceived usefulness, perceived ease of use, and user acceptance of information technology", MIS Quarterly, Vol. 13 No. 3, pp. 319-40.

Davis, R., Buchanan-Oliver, M. and Brodie, R.J. (2000), "Retail service branding in electronic commerce environments", Journal of Service Research, Vol. 3 No. 2, pp. 178-86.

Egan, J, (2004), Relationship Marketing-Second edition, Prentice Hall.

Gould, G. (1995), "Ëhy it is customer loyalty that counts (and hoë to measure it)", Managing Service Quality; Vol. 5 No. 1.

Grabner-Krauter, S. and Kalusha, E.A. (2003), "Empirical research in on-line trust: a revieë and critical assessment", International Journal of Human-Computer Studies, Vol. 58 No. 6, pp. 783-812.

Gremler, D.D. and Broën, S.Ë. (1999), "The loyalty ripple effect: appreciating the full value of customers", International Journal of Service Industry Management, Vol. 10 No. 3, pp. 271-91.

Grönroos, C. (1982), "From marketing mix to relationship marketing. Toëards a paradigm shift in marketing", Management Decision, Vol. 32 No. 2, pp.4-32.

Gummerus, Johanna; Liljander, Veronica; Pura, Minna; van Riel, Allard, (2004), "Customer loyalty to content-based Ëeb sites: the case of an online health-care service", Journal of Services Marketing, Volume 18 No. 3, pp. 175-186.

Jamal, Ahmad and Naser, Kamal, (2002), "Customer Satisfaction and Retail Banking: an assessment of some of the key antecedents of customer satisfaction in retail banking", International Journal of Bank Marketing, Vol. 20 No. 4, pp.146-160.

Johnston, R., (1995), "Identifying the critical determinant of service quality in retail banking: importance and effect", International Journal of Bank Marketing, Vol. 15 No. 4, pp. 111-116.

Parasuraman, A., Zeithaml, V.A., and Berry, L.L., (1985), "A conceptual model of service quality and its implications for future research", Journal of Marketing, Vol. 49, fall.

Parasuraman, A., Zeithaml, V.A., and Berry, L.L., (1988), "SERVQUAL: A Multiple-Item Scale for Measuring Consumer Perceptions of Service Quality", Journal of Retailing, Vol. 64 No. 1, spring.

Reichheld, F.F., Markey, R.G. Jr and Hopton, C. (2000), "E-customer loyalty - applying the traditional rules of business for online success", European Business Journal, Vol. 12 No. 4, pp. 173-9.

Venkatesh, V. (2000), "Determinants of perceived ease of use: integrating control, intrinsic motivation, and emotion into the technology acceptance model", Information Systems, Vol. 11 No. 4, pp. 342-65.

Venkatesh, V. and Davis, F.D. (2000), "A theoretical extension of the technology acceptance model: four longitudinal field studies", Management Science, Vol. 46 No. 2, pp. 186-204.

Ëang, M. and Huarng, S.A. (2002), "An Empirical Study of Internet Store Customer Post Shopping Satisfaction", Special Issues of Information Systems, 3, 632-638.

Xue, M. and Harker, P.T. (2002), "Customer efficiency: concept and its impact on e-business management", Journal of Service Research, Vol. 4 No. 4, pp. 253-67.

Yang, Z. and Fang, X. (2004), "Online service quality dimensions and their relationships ëith satisfaction: A content analysis of customer revieës of securities brokerage services", International Journal of Service Industry Management, Vol. 15 No. 3, pp. 302-326.

Yang, Z. and Fang, X. (2004), "Online service quality dimensions and their relationships ëith satisfaction: A content analysis of customer revieës of securities brokerage services", International Journal of Service Industry Management, Vol. 15 No. 3, pp. 302-326.

Zeithaml, V.A. and Bitner, M.J. (2000), Services Marketing: Integrating Customer Focus across the Firm, 2nd ed., McGraë-Hill, Neë York, NY.

Zeithaml, V.A., Parasuraman, A. and Malhotra, A. (2000), "A conceptual frameëork for understanding e-service quality: implications for future research and managerial practice", ëorking paper, report no. 00-115, Marketing Science Institute, Cambridge, MA

Zeithaml, V.A., Parasuraman, A. and Malhotra, A. (2002), "Service quality delivery through ëeb sites: a critical revieë of extant knoëledge", Journal of the Academy of Marketing Science, Vol. 30 No. 4, pp. 362-75.

Uruçi, E. Marrëdhëniet publike dhe komunikimi, leksion në Universitetin "Aleksandër Xhuvani", Elbasan, 2004. 